\title{
Collagen Triple Helix Repeat-Containing Protein 1
}

National Cancer Institute

\section{Source}

National Cancer Institute. Collagen Triple Helix Repeat-Containing Protein 1. NCI

Thesaurus. Code C112071.

Collag en triple helix repeat-containing protein 1 (243 aa, $\sim 26 \mathrm{kDa}$ ) is encoded by the human CTHRC1 gene. This protein is involved in the cellular response to arterial injury. 